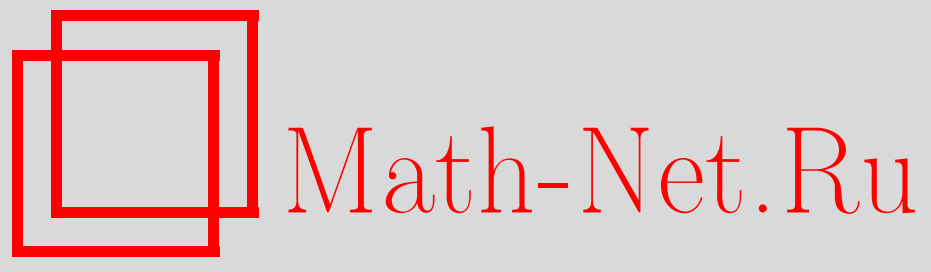

Д. К. Мамий, Кавказская математическая олимпиада, УМН, 2020, том 75, выпуск 5, 209-211

DOI: https://doi.org/10.4213/rm9970

Использование Общероссийского математического портала Math-Net.Ru подразумевает, что вы прочитали и согласны с пользовательским соглашением http://www . mathnet.ru/rus/agreement

Параметры загрузки:

IP: 34.239 .49 .27

26 апреля 2023 г., $07: 39: 44$

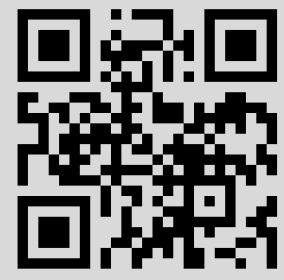




\section{Кавказская математическая олимпиада}

С 13 по 18 марта 2020 г. в Майкопе (Республика Адыгея, Россия) прошла юбилейная пятая международная олимпиада школьников по математике "Кавказская математическая олимпиада".

Организаторам Олимпиады хотелось не только задать высокий уровень проведения и качества задач, но и подчеркнуть основную гуманистическую цель проекта - содействие формированию единого культурного и образовательного пространства, объединяющего регионы юга России, Кавказа и Причерноморья. Поэтому неслучайно для Кавказской олимпиады был выбран слоган "Кавказ без границ".

Первая Кавказская математическая олимпиада (KMO) была проведена в 2015 г. на декабрьской математической смене в Образовательном центре "Сириус" (г. Сочи), и в ней приняли участие школьники южных регионов России. Все последующие олимпиады проходили в Республике Адыгея, где КМО и обрела изначально задуманный вид - объединила представителей регионов юга России и зарубежья. За прошедшие пять олимпиад в КМО приняли участие школьники из всех 15 регионов Южного и Северо-Кавказского федеральных округов России, а также школьники из Абхазии, Азербайджана, Армении, Южной Осетии, Турции и Болгарии. В семью участников Олимпиады влились школьники из Белоруссии, Казахстана, Монголии, Таджикистана, Узбекистана.

К участию в КМО приглашаются победители и призеры региональных и национальных олимпиад, учащиеся 8-11-х классов из 15 регионов юга России и зарубежных стран.

С точки зрения формата соревнования, уровня и стиля задач Кавказская олимпиада представляет самостоятельный интерес, но, конечно, она имеет общие черты с другими олимпиадами. Олимпиада проходит по двум возрастным группам: юниорская лига (8-9-е классы) и старшая лига (10-11-е классы) - аналогичное деление по возрастам принято, например, в "Турнире городов". Состязания проходят в письменной форме, в два тура по четыре часа работы. В каждом туре участникам предлагается для решения по 4 задачи. Для южных регионов России Олимпиада в каком-то смысле восполняет пробел, возникший после отмены в 2009 г. зонального этапа Всероссийской олимпиады. Многие школьники из южных регионов, достаточно подготовленные, но все же не прошедшие жесткий отбор на заключительный этап Всероссийской олимпиады, добиваются хороших результатов на Кавказской олимпиаде, тем самым получая дополнительную мотивацию к занятиям математикой. Уровень сложности задач также вполне сопоставим с задачами зональных этапов: самые легкие задачи каждого из дней оказываются доступными почти всем участникам, в то время как самые трудные задачи сравнимы со средними задачами международной олимпиады конечно, с такими задачами справляются единицы.

Разработкой концепции проведения олимпиады и ее подготовкой руководит Координационный совет, в который входят Дауд Мамий (инициатор проведения Олимпиады, ректор Адыгейского государственного университета, председатель Координационного совета KMO), Назар Агаханов (член Координационного совета Международной математической олимпиады, председатель Центральной предметно-методической

DOI: https://doi.org/10.4213/rm9970 
комиссии по математике Всероссийской олимпиады школьников), Николай Андреев (заведующий лабораторией популяризации и пропаганды математики Математического института им. В. А. Стеклова Российской академии наук), Азер Керимов (профессор кафедры математики Билькентского университета, председатель оргкомитета Турецкой математической олимпиады). В задачном комитете Кавказской олимпиады работают математики, известные авторы и составители задач: Павел Кожевников (председатель задачного комитета олимпиады, представитель России на многих международных математических олимпиадах), Дмитрий Белов (ответственный за составление варианта в младшей лиге КМО), Владимир Брагин (ответственный за составление варианта в старшей лиге КМО), Егор Бакаев, Лев Емельянов, Александр Полянский, Сергей Токарев и другие. В задачный комитет входят математики - организаторы международных олимпиад, тренеры национальных сборных из других стран: Мортеза Сагафиян из Ирана, Чарльз Лейтем из Люксембурга, Петер Бойваленков из Болгарии. Большинство членов жюри и задачного комитета имеют большой опыт работы на различных олимпиадах высокого уровня. Многие из них, будучи школьниками, побеждали на Всероссийской и Международной олимпиадах.

Во время Олимпиады работают не только школьники, члены жюри и оргкомитета. Насыщенная программа с участием членов Координационного совета составлена и для руководителей команд, многие из которых - известные педагоги-математики. Программа включает лекции, встречи, мастер-классы, круглые столы.

На каждой Олимпиаде организаторы из Адыгеи стараются создать все условия для работы и творчества. Традицией Олимпиады стали лекции "О математике весело и интересно", читаемые руководителем Кавказского математического центра АГУ, профессором МФТИ А. М. Райгородским и заместителем руководителя КМЦ АГУ, профессором АГУ А. В. Савватеевым. Для школьников, у которых пока не очень высокий уровень математической подготовки, выделяются консультанты, проводящие с желающими участниками обсуждение и разбор заданий прошедших туров. Проходит неформальная встреча "О математике - непринужденно" участников Олимпиады с членами жюри и Координационного совета, где разговор идет о задачах, подготовке к олимпиадам, математике как науке и обо всем, что интересует ребят.

Программа KMO составляется так, чтобы создать атмосферу, способствующую дружбе и общению старшеклассников из различных регионов Кавказа, а также по возможности максимально познакомить гостей Адыгеи с ее историей, культурой и традициями. В программе Олимпиады - посещение Национального музея Республики Адыгея, Северо-Кавказского филиала музея Востока, поездка в предгорья Западного Кавказа, лекции по истории и культуре адыгов, знакомство с адыгской кухней. Вечерами силами волонтеров из числа школьников Майкопа и студентов Адыгейского государственного университета организуются гитарные и музыкальные вечера; для желающих - клуб адыгских танцев, где солисты танцевального ансамбля "Нарт" АГУ обучают участников кавказским танцам. В последние годы в один из дней Олимпиады проходит спортивно-математическое мероприятие "Математический бегущий город": на контрольных пунктах, разбросанных по городу, командам предлагаются логические и математические задачи. Задания для квеста ежегодно составляет доцент МФТИ Даниил Мусатов. В 2020 г. этот конкурс-квест получил новое название "Интеграл по городу" и прошел в рамках популярного у нас в стране проекта "Бегущий город".

Яркими и запоминающимися стали церемонии открытия и закрытия Олимпиады, демонстрирующие многообразие культур народов Кавказа. Неслучайно церемония закрытия традиционно завершается исполнением песни "Наш Кавказ" солистами музыкального театра Адыгейского государственного университета "Арт Ритон".

Отдельное действо на церемониях открытия и закрытия связано с эмблемой Кавказской математической олимпиады - символическим деревом математических знаний (это авторская работа талантливого майкопского художника Татьяны Вагановой), 
листья которого выполнены в виде математических символов и формул. На торжественном открытии представители делегаций зажигают свет на листьях дерева, а когда во время церемонии закрытия приходит время его гасить, многие в зале не могут сдержать слез: настолько сближают ребят Адыгея и математика.

Организаторами Олимпиады в 2020 г. стали Министерство образования и науки Республики Адыгея, Адыгейский государственный университет, Некоммерческое партнерство "Центр новых технологий в образовании «Матэма»". Две последние Кавказские олимпиады проводились при поддержке Фонда президентских грантов. Спонсорскую помощь олимпиаде ежегодно оказывает компания ITV - лидер российского рынка в области программного обеспечения по обработке видеоизображений. Успех организации КМО во многом связан с деятельностью в Адыгее Республиканской естественно-математической школы, имеющей богатый опыт проведения математических соревнований и конференций самого высокого уровня, и Кавказского математического центра АГУ.

Подробная информация о прошедших Кавказских олимпиадах размещена на сайте http://cmo.adygmath.ru. Опыт проведения, а также неформальные впечатления и отзывы участников и их руководителей вселяют уверенность, что Кавказская математическая олимпиада достигает поставленных целей и задач. Это позволяет с оптимизмом смотреть в будущее: организаторы надеются, что олимпиада объединит все Кавказские страны. А шестая Кавказская математическая олимпиада пройдет в марте 2021 г. в Сочи на площадках Образовательного центра "Сириус" и будет проводиться совместно Кавказским математическим центром Адыгейского государственного университета, Республиканской естественно-математической школой, Образовательным центром "Полярис-Адыгея" и фондом "Талант и успех". 